\title{
通風性能の定量的評価手法に関する研究 STUDY ON OF THE EVALUATION METHOD OF A CROSS VENTILATED BUILDING PERFORMANCE
}

\author{
赤林 伸一*, 佐々木 淑貴**, 坂口 淳***, 富 永 禎 秀**** \\ Shin-ichi AKABA YASHI, Yoshitaka SASAKI, Jun SAKAGUCHI \\ and Yoshihide TOMINAGA
}

\begin{abstract}
In this study, we evaluate cross ventilation by the multi zone network airflow simulation and the CFD. Cross-ventilated detached house is evaluated. Quantitative evaluation of the effect of cross ventilation is carried out.

The analytic object is a standard residence model. The k-e turbulence model simulates the flow. The purpose of this simulation is to calculate indoor airflow velocity distribution.

The muti-zone airflow network model analysis using TRNSYS-COMIS simulates the indoor temperature. Two different analyses are coupled, so that the long-term simulation is realized.

This paper proposes to report on the outline of the evaluation index of natural cross ventilation performance. This paper has the point to (1) locality, (2) location, (3) building performance as factors which influenced indoor wind velocity, and show the outline of the evaluation method for natural cross ventilation performance
\end{abstract}

Keywords : Cross ventilation evaluation index, Local index, Site index, Building performance index 通風性能評価, 地域指標, 立地指標, 建物性能指標

1.はじめに

住宅等の通風性能を定量的に評価するためには、外部風、室内外 温度差に基づく室内の通風性状の時間変化を $\mathrm{CFD}$ 等の手法により明 らかにする必要がある。この場合室内外温度差のみによる通風性状 の变化は比較的容易に明らかにすることが可能である。一方、外部 風による通風性状の変化は、地域条件、立地条件、建物形状等に大 きく影響され、定量的に評価することは極めて困難である。

そこで、別報（文献 1 ）では通風性能を評価するため、住宅モデ ルを対象に室内外気流を数值解析、熱負荷・換気回路網計算を連成 させて解析し、評価する方法について検討を行った。しかしながら、 建物周囲の状況、地域性による通風効果の違いなどを考慮する必要 等が指摘された。

通風性能を定量的に評価するためには、同一住宅モデルが過疎地 に立地する場合と市街地に立地する場合の通風性能の違いや、同一 住宅モデルが寒冷地から温暖地一移動することによって、地域性の 違いによる通風性能の変化を評価できる指標が必要と考えられる。 室内の気流分布に特に影響が大きいと思われる要素は、地域によ る気象条件の影響（本稿ではこれを「(1)地域指標」と定義）、建物の周 囲状況の影響（「(2)立地指標」と定義）、建物の形状・空の配置等の違 いによる影響（「(3)建物性能指標」と定義）の3 要素と考えられる。
本稿では、最終的にこの3つの指標を使用して総合的通風性能評価 指標（図 1）を提案することを目的とする。

\section{2. 地域指標}

図 2 に地域指標の概念を示す。人体が屋外気象条件から受ける影 響の地域的な相異を温熱環境評価尺度により評価する。人体の上方 には仮想の屋根（完全黒体：長、短波長吸収率＝1）を想定し、直接、
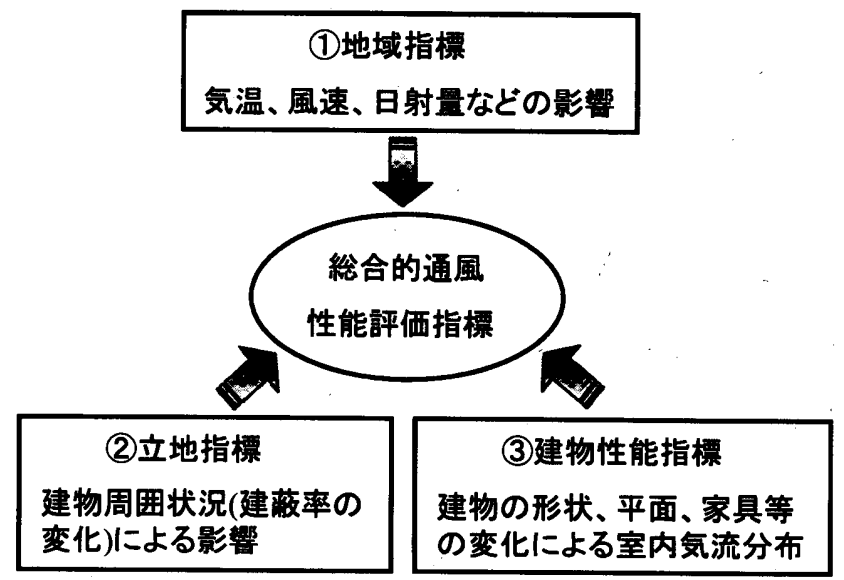

図 1 通風性能評価指標の概念

\footnotetext{
* 新潟大学大学院自然科学研究科 教授. 工博

** 新潟大学大学院自然科学研究科 大学院生・修士 (工学)

*** 県立新潟女子短期大学生活科学科 講師 ·博士 (工学)

**** 新潟工科大学工学部建築学科 助教授 ·博士 (工学)
}

Prof., Dept. of Architecture, Faculty of Engineering, Niigata Univ., Dr. Eng. Graduate Student, Division of Science and Technology, Graduate School of Niigata Univ., M. Eng.

Lecturer, Dept. of Human Life and Environmental Niigata Women's College, Dr. Eng

Assoc. Prof., Dept. of Niigata Institute of Technology, Dr. Eng. 
人体は日射の影響を受けないと仮定する。放射熱は、屋根面、床面 の形態係数をそれぞれ 0.5 として算出する。また、人体周囲には壁 は無いと想定し、人体は外部風速の影響を直接受けるものとする。 外部風速は、 $1 / 4$ 乗則により人体の呼吸域付近である地上高さ $1.5 \mathrm{~m}$ に換算した值を用いている。

\section{1 気象データ}

気象データには日本建築学会拡張アメダス気象データ文7)を用い、 全国 842 地点を対象に解析を行う。SET* 算出に必要な気温、湿度、 気流速度注 1)、日射量等は標準年の気象デー夕を使用する。また、表 1 にSET*の解析条件を示す。

2.2 通風デグリアワーの定義 (CVDH：Cross Ventilation Degree Hour)

本稿では地域評価指標として通風デグリアワー（以下 CVDH と記 述）を提案する。図 3 にCVDH の概念を、図 4 にCVDHの解析フロー を示す。SET*を算出する際の風速值は、人体周辺の熱対流を考慮し、 不感気流の限度して最小風速を $0.3 \mathrm{~m} / \mathrm{s}$ 、また、実風速が $3.0 \mathrm{~m} / \mathrm{s}$ を超 えている場合は最大風速を $3.0 \mathrm{~m} / \mathrm{s}$ とする。 $\mathrm{CVDH}$ は基準最小風速 $(0.3 \mathrm{~m} / \mathrm{s})$ 時の SET* $(1)$ の時間変化を計算し、快適範囲の上限である SET*が $26^{\circ} \mathrm{C}$ を超えている時間を対象に、各地域の実風速データによ る $\mathrm{SET}^{*}(2)$ と比較し、下限值の $\mathrm{SET}^{*}$ を $23^{\circ} \mathrm{C}$ として時間数に SET*差 (SET* (1) $\left.-\mathrm{SET}^{*}(2)\right)$ を乗じて算出する。

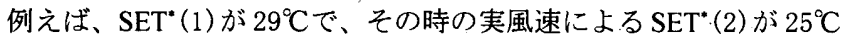
の場合には SET の差は $4^{\circ} \mathrm{C}$ となり、その時間数を乗じて CVDH を算出
する。また、SET* (2)が $26^{\circ} \mathrm{Cを}$ 超え、 $27^{\circ} \mathrm{C}$ の場合には、その時の $\mathrm{SET}^{*}$ の差 $2^{\circ} \mathrm{C} は 、 \mathrm{SET}^{*}(2)$ が快適範囲に入っていないため、CVDH 算出の対 象外とする。更に、SET* (2) が $23^{\circ} \mathrm{C}$ 以下となり、 $22^{\circ} \mathrm{C}$ の場合には SET* の快適範囲の下限值である $23^{\circ} \mathrm{C}$ とて SET"の差を $6{ }^{\circ} \mathrm{C}$ と、時間数 を乗じて CVDH を算出する。

すなわち、CVDHはそれぞれの地域において、気流のみの影響によ り、SET*が $26^{\circ} \mathrm{C}$ を超えている時間に人体の体感温度をどの程度低下 させるかを非暖房期間を対象とし、地域における相対的評価をするた めの指標である。

\section{3 解析条件}

表 1 にCVDH の解析条件を示す。CVDH の算出は非暖房期間の非 就寝時を対象とする。日平均気温が $18^{\circ} \mathrm{C}$ を下回る期間を暖房期間と し、それ以外の期間を非暖房期間と定義する。期間の初めは、日平 均気温 $18^{\circ} \mathrm{C}$ を境に5 日閒連続 $18^{\circ} \mathrm{C}$ を回り、その後、5 日間連続 $18^{\circ} \mathrm{C}$ を回る期間の初めの日とし、期間の終わりは逆に 5 日間連続 $18^{\circ} \mathrm{C}$ を下回る日の初めの日と定義する。非就寝時は、6 時から 23 時 と定義する。

\section{4 解析結果}

図 5 に全国のCVDH マップを示す。北から南下するに従い、相対 的にCVDH は大きくなる。また、海沿いで大きく、内陸になるに従 い小さくなる。北海道でも海沿いの松前では $4792{ }^{\circ} \mathrm{Ch}$ 、北陸の富来

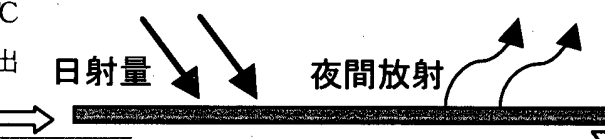

表 1 SET* およびCVDH の解析条件

\begin{tabular}{c|c}
\hline 気象データ & $\begin{array}{c}\text { 拡張アメダス気象データ } \\
\text { (気温、風速、湿度等) }\end{array}$ \\
\hline 基準風速 & $0.3 \mathrm{~m} / \mathrm{s}$ (最小)、3.0m $/ \mathrm{s}$ (最大) \\
\hline \multirow{2}{*}{ 仮想屋根 } & $\begin{array}{c}\text { 完全黒体 } \\
\text { 長波·短波長吸収率=1 }\end{array}$ \\
\hline \multirow{2}{*}{ 着衣量 } & $0.5 \mathrm{clo}(7 \sim 9$ ) \\
\cline { 2 - 2 } & $1.0 \mathrm{clo}(12 \sim 2$ 月) \\
\cline { 2 - 2 } 代謝量 & $0.75 \mathrm{clo}(3 \sim 6 、 10,11$ 月) \\
\hline 形態係数 & $1 \mathrm{Met}$ \\
\hline 非暖房期間 & 日平均気温: $18^{\circ} \mathrm{C}$ 以上 \\
\hline 非就寝時 & $6 \sim 23$ 時 \\
\hline
\end{tabular}

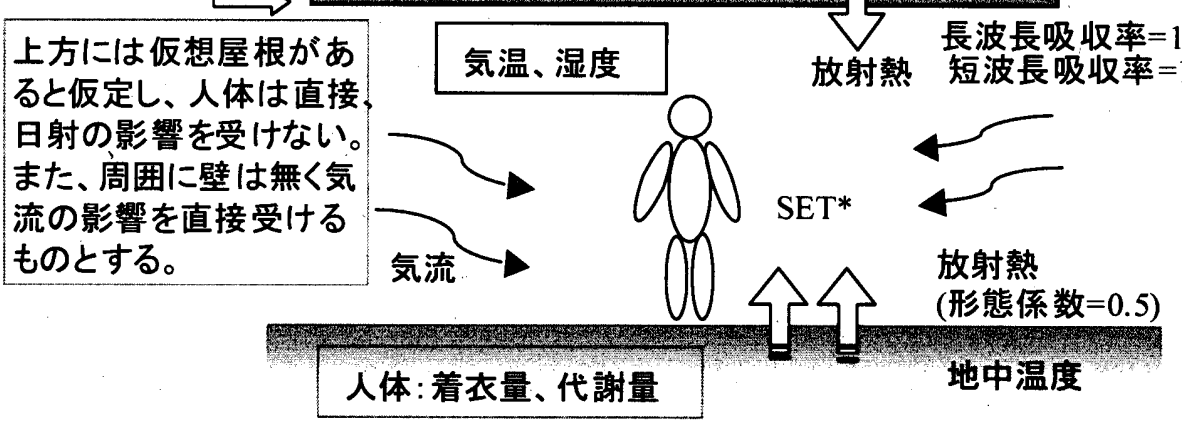

図 2 人体が屋外気象条件から受ける影響
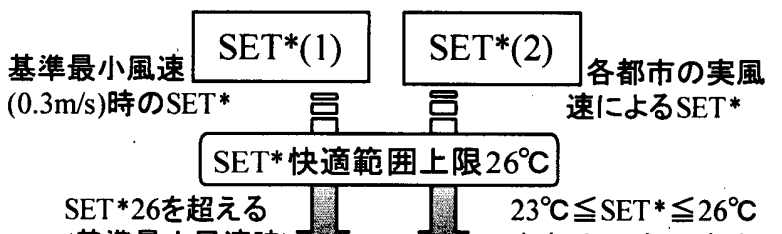
(基準最小風速時) (各都市の実風速時)

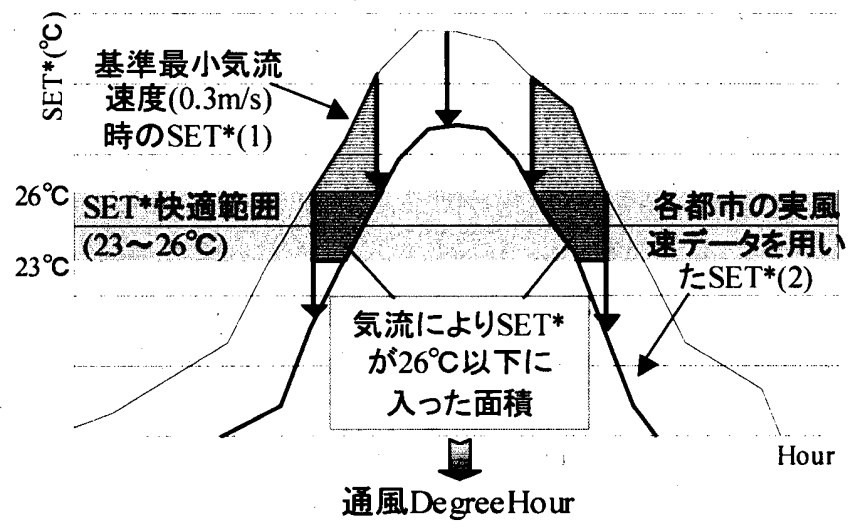

図3通風デグリアワー(CVDH) の概念

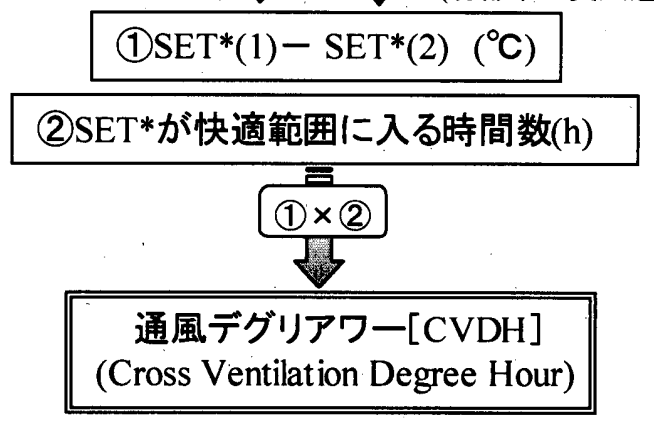

図 4 通風デグリアワー(CVDH) の解析フロー 
で $4769^{\circ} \mathrm{Ch}$ 、新舄で $4849^{\circ} \mathrm{Ch}$ と CVDH は大きくなっている。これは 内陸に比べ、海沿いの都市で風速が速く、通風による体感温度低下 の効果が大きいことが原因と考えられる。

九州、沖縄における CVDH は特に大きく、九州の福岡で $5474^{\circ} \mathrm{Ch}$ 、

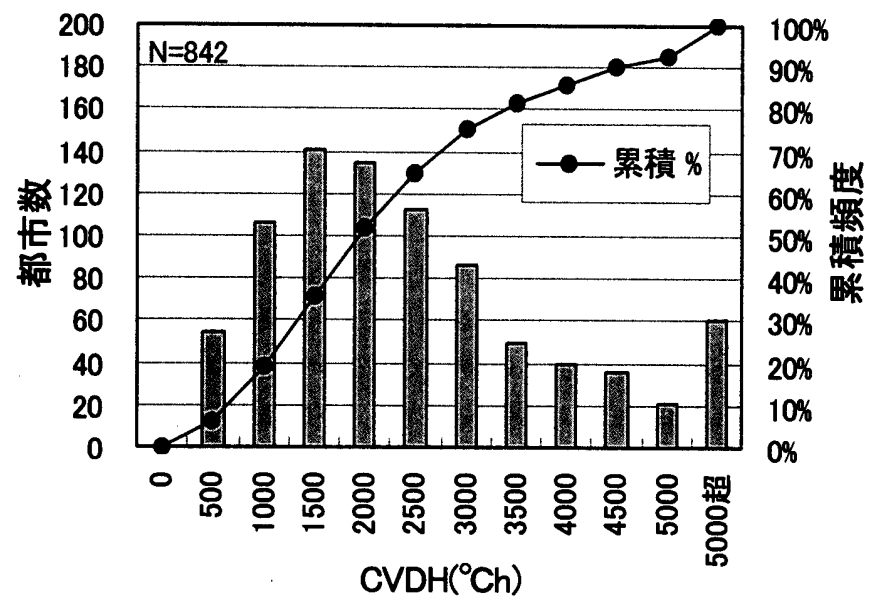

图 $6 \mathrm{CVDH}$ の頻度分布
宮崎で $4149^{\circ} \mathrm{Ch}$ 、沖縄ではほとんどの都市で $9000^{\circ} \mathrm{Ch}$ を超えている。 これは北海道、東北地方等に比べ非暖房期間が相対的に長いため、 通風の効果が長期間得られることに起因する。

CVDH は各地域の通風による体感温度低下の効果が期待できる外 部風のポテンシャルエネルギー量を示している。このためCVDH は 非暖房期間の日数、及び風速に関係が深い。

\section{5 地域指標の評価}

図 6 に CVDH の頻度分布を示す。CVDH は $1000 \sim 2000^{\circ} \mathrm{Ch}$ の都 市が最も多く、全体の約 3 割を占める。表 2 に本稿で提案する地域 指標のグレードを示す。Grade 1 から Grade 5 まで 5 段階に分け、評

表 2 地域指標のグレード

\begin{tabular}{|c|c|c|}
\hline & $\begin{array}{l}\text { CVDH } \\
\left({ }^{\circ} \mathrm{Ch}\right)\end{array}$ & 主要都市の例 \\
\hline Grade1 & 4500以上 & 新潟、福岡、 \\
\hline Grade2 & 3000 4500末茜 & 宫古屋等 \\
\hline Grade3 & 2000～3000末满 & 大阪等 \\
\hline Grade4 & 1000～2000末淽 & 山形、字都宮、奈良等 \\
\hline Grade5 & 0〜1000未満 & 带広、軽井沢、鞍岡等 \\
\hline
\end{tabular}

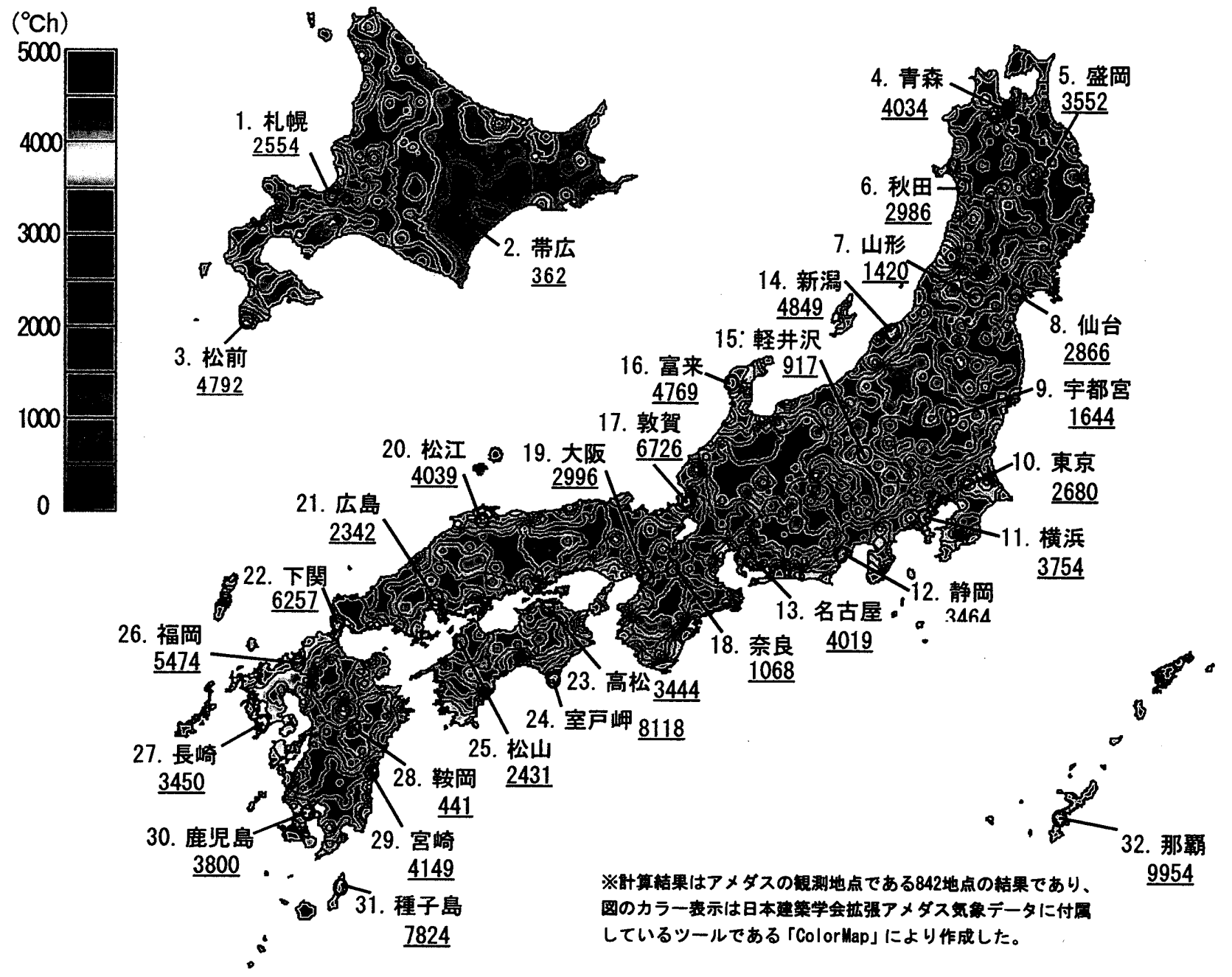

図 5 全国の通風デグリアワー(CVDH) マップ 
価を行う。表中の都市は図 5 に示した主要な都市を示し、Grade 1 の都市は新潟、福岡、沖縄等となる。

\section{6 地域指標のまとめ}

本稿では、通風性能評価指標の一指標である地域指標の評価を 行った。

(1) CVDH は地域の通風による体感温度低下の効果を示す指標であ る。全国のCVDH マップを算出し 5 段階のグレードに分け評価指標 を作成した。

(2) CVDH は北から南の地域、また内陸から平野部、海沿いいいくに 従い相対的に大きくなっている。CVDHは非暖房期間の日数、風速 の速さに大きな影響を受けるため、非暖房期間が長い九州、沖縄の 都市で特に大きくなる。

\section{3. 立地指標}

住宅の通風性状は隣接建物の影響を強く受ける。既報の論文では 住宅壁面の風圧俰数の実測、風洞実験及び気密性能の実測、また建 蔽率を変化させた場合の風圧分布に関する風洞模型実験 2 ( 4)などに より通風量予測を行っている。本稿では建蔽率が通風性能に及ぼす 影響を立地指標と定義する。

単純住宅モデルを対象として、通風時の室内外気流分布、通風量 を上空の風向、建蔽率をパラメータとして数值流体解析により明ら
かにし、総合通風性能評価指標の一つである立地条件（建蔽率）の 変化に伴う室内気流分布、通風量の変化を定量的に評価することを 目的とする。

\section{1 解析対象}

図 7 に対象とした単純住宅モデルの外観、メッシュ分割(平面)を 示す。対象住宅モデルの東西南北の各壁面には $0.81\left(\mathrm{~m}^{2}\right)(0.9 \times$

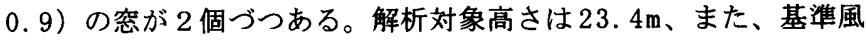
速は $3.8 \mathrm{~m} / \mathrm{s}$ とし、基準風速の高さは解析対象建物の影響を受けな い高さとして棟高の 4 倍の高さを仮定している。

\section{2 解析条件}

乱流モデルには標準 $\mathrm{k}-\varepsilon$ モデルを用いる。数值計算には、沉用 CFD プログラム（CFD2000）を使用する。建蔽率０\%（単独建物） 以外は、計算領域が周囲に連続していると仮定（図 8 参照）して周 期境界条件を採用し、計算領域上空に一定風速を与え、流れの駆動 力とした。建蔽率泩2) は $0 ， 5 ， 10 ， 20 ， 30 ， 40 \%$ とする。解析対 象モデルの対称性から、各建蔽率について風向 S $(\mathrm{N}, \mathrm{E}, \mathrm{W}) 、 \mathrm{SSW}$ (NNE, ENE, ESE, SSE, SSW, WSW, WNW, NNW)、SW (NE, SE, NW) の解析を行い、16 風向全ての解析を行う。表 3 に解析条件を示す。

\section{3 解析結果}

\section{1) 室内気流分布の解析結果}

図 9、10に対象モデルの室内気流分布（図中の数字は、棟高の 4 倍

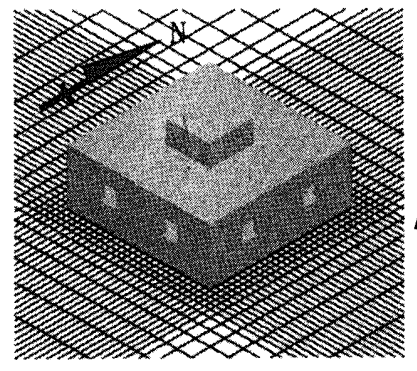

(1) 外観

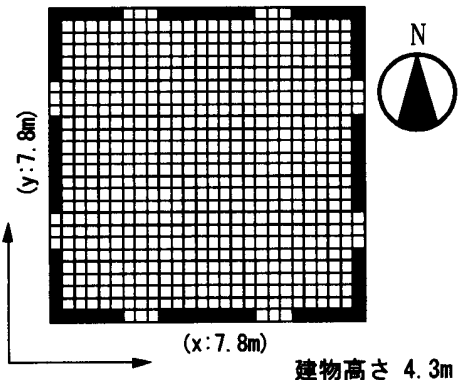

（2）メッシュ分割（平面）

図 7 単純住宅モデル

表 3 解析条件

\begin{tabular}{l|l}
\hline 乱流モデル & 標準k $-\varepsilon$ モデル \\
\hline 解析建蔽事 $(\%)$ & $0,5,10,20,30,40$ (道路を含む) \\
\hline 解析風向 & $\mathrm{S}, \mathrm{SSW}, \mathrm{SW}$ \\
\hline 室内解析メッシュ & $26(\mathrm{x}) \times 26(\mathrm{y}) \times 14(\mathrm{z})$ メッシュ \\
\hline 側密開口面積 $\left(\mathrm{m}^{2}\right)$ & $0.81(=0.9 \times 0.9)$ \\
\hline
\end{tabular}

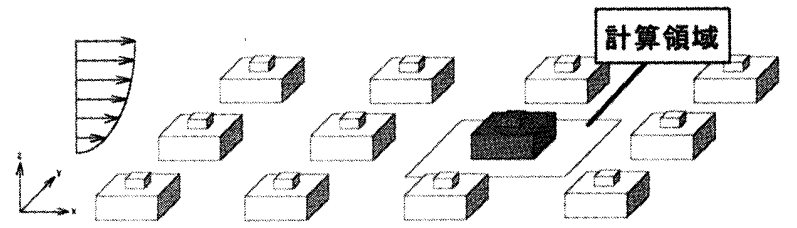

図 8 計算領域が周囲に連続している概念図

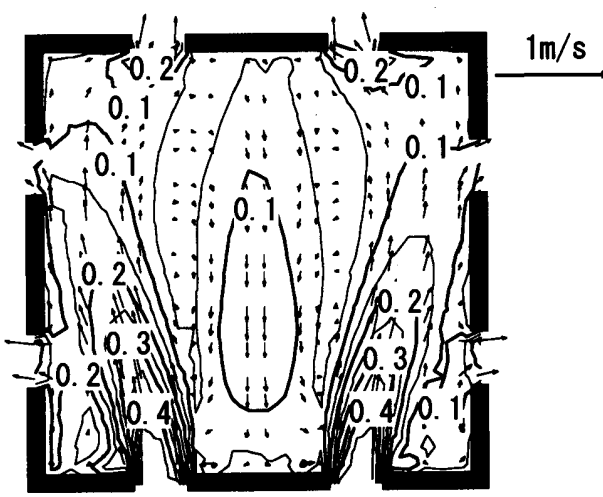

平面 $(\mathrm{H}=1.35 \mathrm{~m})$

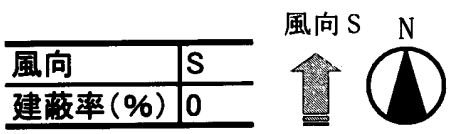

(1) 建蔽率 $0 \%$

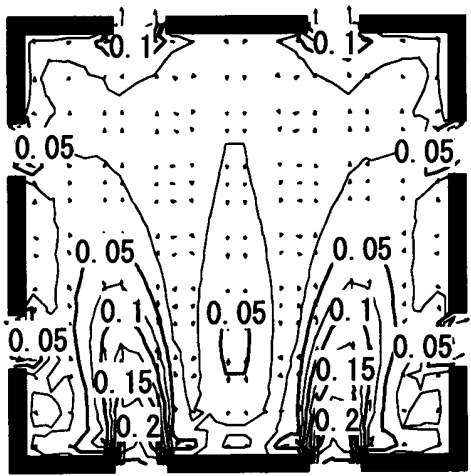

平面 $(H=1.35 \mathrm{~m})$

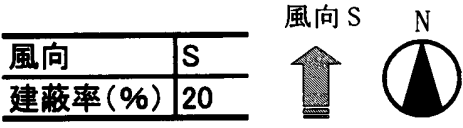

(2) 建蔽率 20\%

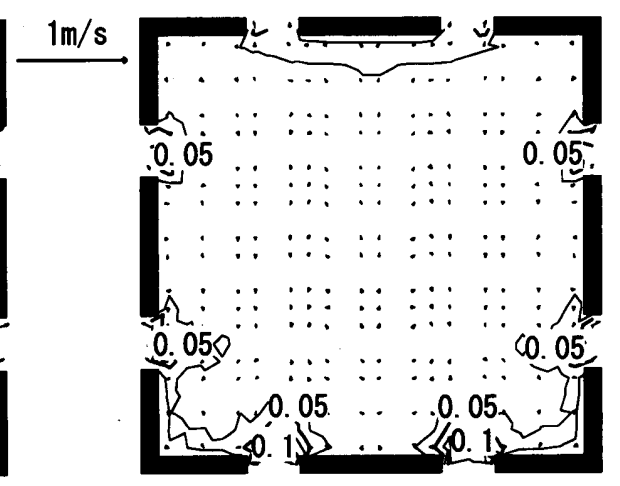

平面 $(H=1.35 \mathrm{~m})$

風向 $\mathrm{S}$

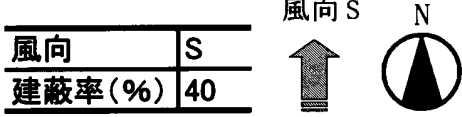

(3) 建蔽素 $40 \%$

图 9 室内気流分布（風向 $S$ ，基準風速 $3.8 \mathrm{~m} / \mathrm{s}$ ） 
の高さを基準風速とする風速比）を示す。

(1)風向 S(図 9)

建蔽率 $0 \%$ では流入開口から流出開口へと明確な通気輪道が形成 される。建蔽率 $20 \%$ の場合には建蔽率０\%に比較し風速比は室全体 の平均で 5 割程度に小さくなるが、流入開口から流出開口へと通気 輪道が形成される。建蔽率 $40 \%$ では、風上側周辺建物の影響により、 流入風速比は 0.1 程度となり、室内では風速比が 0.05 以下の気流 が一様に分布している。

(3)風向 SW（図 10）

建蔽率 0\%では南空、西空から外気が流入しそれぞれ主流力向で ある東空、北空へと明確な通気輪道を形成する。建蔽率 $20 \%$ の場合 は風向 S, SSW と同様に建蔽率 $0 \%$ と比較して室全体の風速比は 5 割程度に小さくなるが、南空、西空から外気が流入しそれぞれ主流 方向である東空、北空へと通気輪道を形成する。建蔽率 $40 \%$ では風 速比 0.15 程度の外気が流入するが、室中央での風速比は 0.05 程度 である。

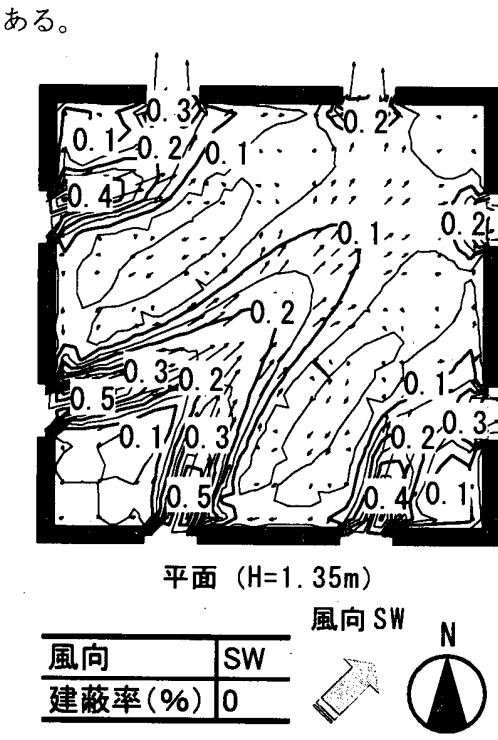

(1) 建蔽率 $0 \%$
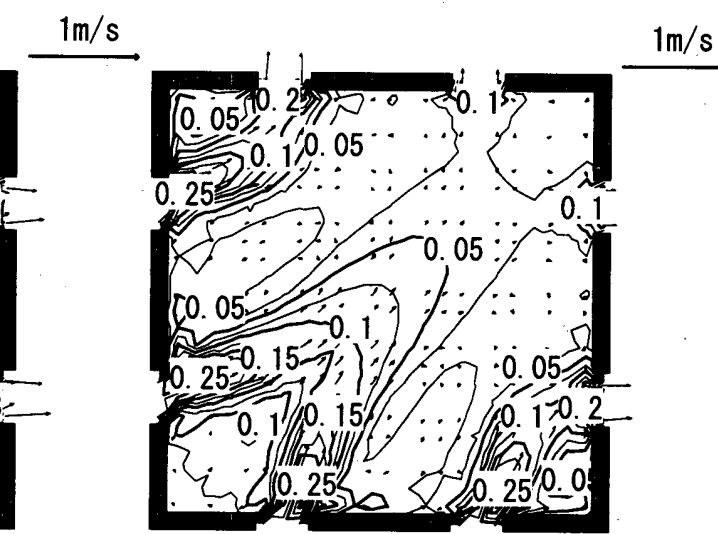

平面 $(H=1.35 \mathrm{~m})$ 風向 SW

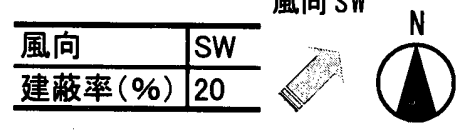

(2) 建蔽率 $20 \%$
2）建蔽率、風向变化による通風量比

図 11 に建蔽率および風向の変化による各壁面空の流入、流出風量 比を示す。風量比は、風向 $\mathrm{S}$ 、建蔽率 $0 \%$ の時の通風量を $\mathrm{Q}_{0 \mathrm{~s}}$ とし、 各風向、建蔽率の流入、流出風量を $\mathrm{Q}_{0 \mathrm{~s}}$ で基準化して示す。

(1)風向 S（図11（1））

通風量比は建蔽率 $20 \%$ で建蔽率 $0 \%$ の約 5 割、建蔽率 $40 \%$ で建 蔽率 $0 \%$ の約 2 割まで低下寸る。南側空のみから流入し北側、東側、 西側空から流出する。

(3)風向 SW（図 $11 （ 2 ）$ )

建蔽率 $0 \%$ は風向 $\mathrm{S}$ と比較し通風量比は約 1.3 倍となる。どの建 蔽率においても風向 S、SSW と比べ、通風量比は大きくなる。流入 風量比は南側、西側空からほぼ同じ割合で流入し、北側、東側空か ら流出する。

図 10 室内気流分布（風向 $S W$ ，基準風速 $3.8 \mathrm{~m} / \mathrm{s}$ )

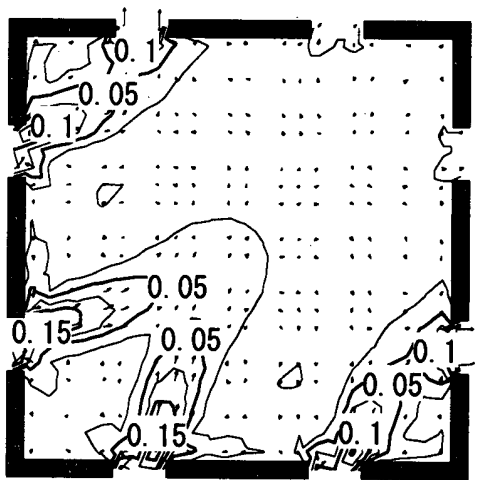

平面 $(H=1.35 \mathrm{~m})$

風向 $S W$

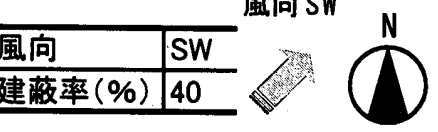

（3）建蔽率 $40 \%$

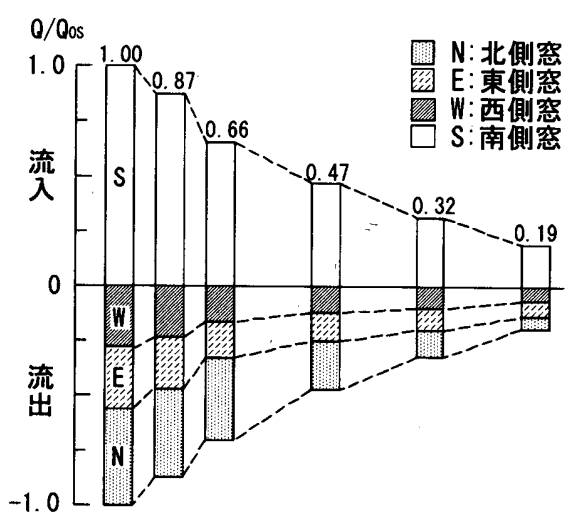

（Oos：風向S，K=0\%の時の通風量）

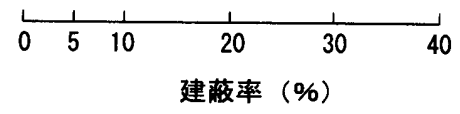

（1）風向 S

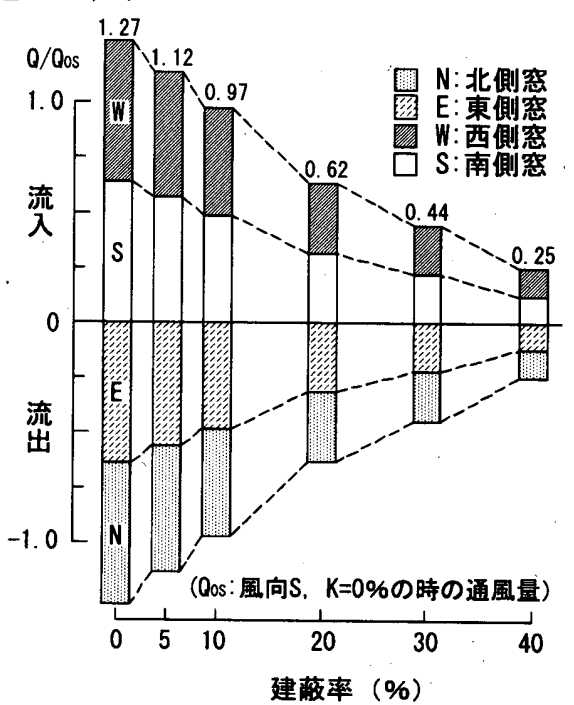

（2）風向 SW

図 11 建蔽率および風向の変化による各壁面空の流入、流出風量比

（流入を十、流出をーとして表示する。風向 S、建蔽率 $0 \%$ \%ときの通風量で基準化する。） 


\section{4 立地指標の評価}

図 12 に建蔽率と平均通風量比の関係を示す。平均通風量比とは各 風向 (解析対象モデルの対称性から、3 風向の解析結果を割り当て 16 風向とした。)の通風量比を単純平均したものである。例えば、あ る住宅の立地する場所の道路を含めた建蔽率が $30 \%$ の場合、図 12 からその住宅の立地指標は 0.31 となる（当該建物の形状は「建物 性能指標」により評価を行うため、ここでは無視する)。立地指標は 対象住宅モデルが、周囲建物群から受ける影響を考慮した通風性 能の評価指標となる。

表 4 に立地指標のグレードを示す。地域指標と同様に、図 12 に示 した平均通風量比をGrade 1 から Grade 5 まで 5 段階に分け、評価

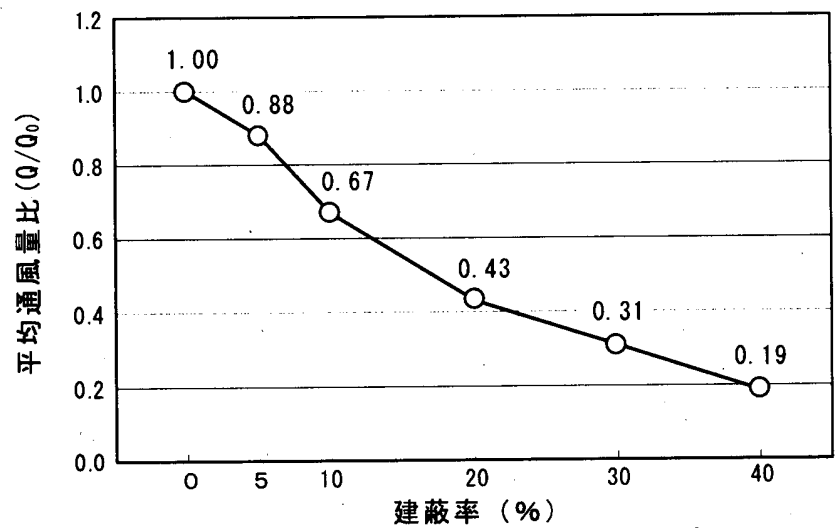

を行う。例えば、対象となる住宅の立地する敷地が建蔽率 $10 \%$ の場 合、その住宅の立地指標は Grade 1 となる。

\section{5 立地指標のまとめ}

本稿では、通風性能評価指標の一つである立地指標の評価指標を 提案した。

(1)建蔽率の変化により、流入風速比は建蔽率 $20 \%$ では $0 \%$ の約 5 割、40\%では 2 割程度まで減少する。室内気流分布も建蔽率 $0 \%$ で 見られた明確な通気輪道は、建蔽率 $40 \%$ ではほとんど見られない。 (2)建蔽率 $0 \%$ では風向 S に比べ、風向 SSWでは通風量比で約 1.2 倍、 風向 SW では約 1.3 倍となる。また、各風向の通風量比は建蔽率 20 \%では $0 \%$ と比較して約 5 割、 $40 \%$ では約 2 割まで減少する。

(3)立地条件の評価指標として、16風向の通風量比を平均した平均通 風量比を算出した。建蔽率 $0 \%$ を 1.00 として、建蔽率 $20 \%$ では $0.43 、 40 \%$ では 0.19 となる。

(4)平均通風量比により 5 段階のグレードに分け立地指標を作成した。

表 4 立地指標のグレード

\begin{tabular}{c|c|c}
\hline & 平均通風量比 & 建蔽率 $(\%)$ の例 \\
\hline \hline Grade1 & 0.60 以上 & 10 \\
\hline Grade2 & $0.40 \sim 0.60$ 未満 & 20 \\
\hline Grade3 & $0.30 \sim 0.40$ 未満 & 25 \\
\hline Grade4 & $0.20 \sim 0.30$ 未満 & 35 \\
\hline Grade5 & $0 \sim 0.20$ 未満 & 40 \\
\hline
\end{tabular}

図 12 建蔽率と平均通風量比の関係

表 5 解析条件

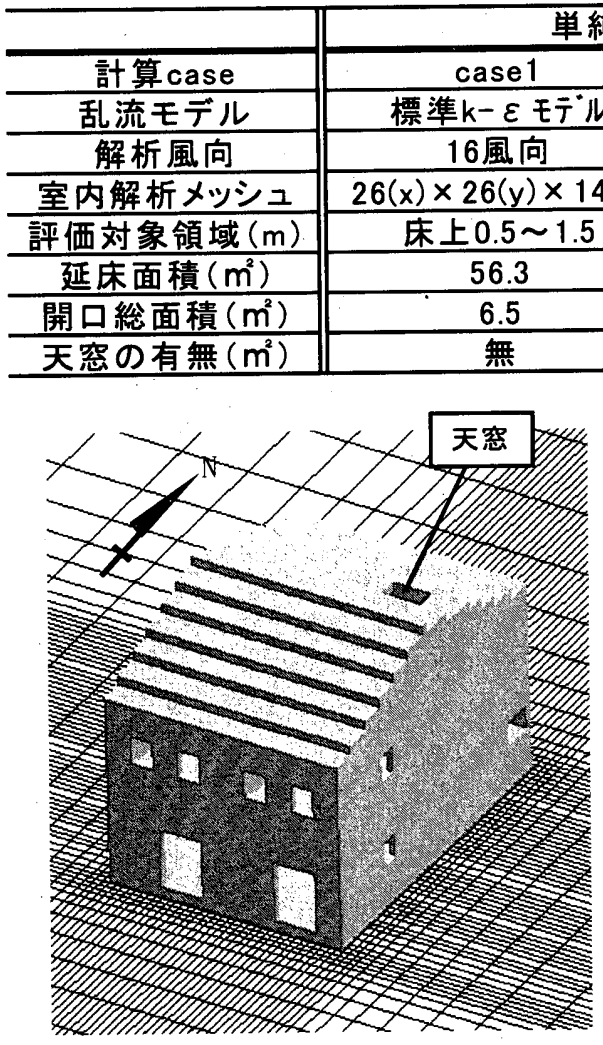

（1）外観 (SE 側面)

単純住宅モデル

標準問題モデル case3

case 2

隼 $\mathrm{k}$ モデル

16風向

$26(x) \times 26(y) \times 14(z)$

16風向

床上 $0.5 \sim 1.5$

\begin{tabular}{|c|c}
\hline 56.3 & 98.3 \\
\hline 6.5 & 15.5 \\
\hline
\end{tabular}

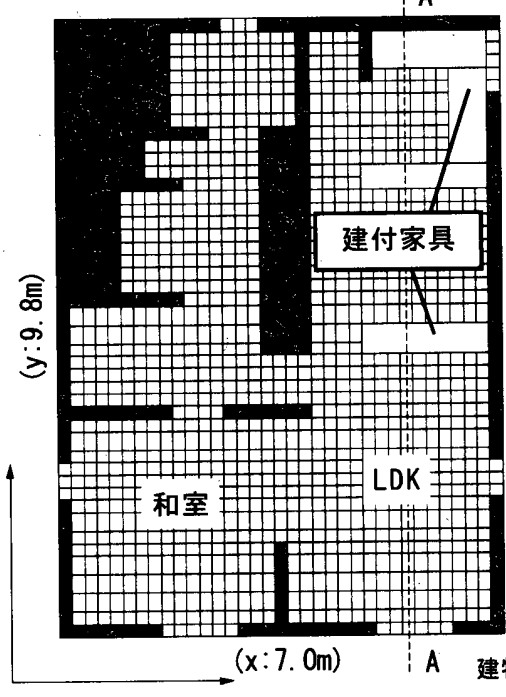

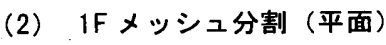

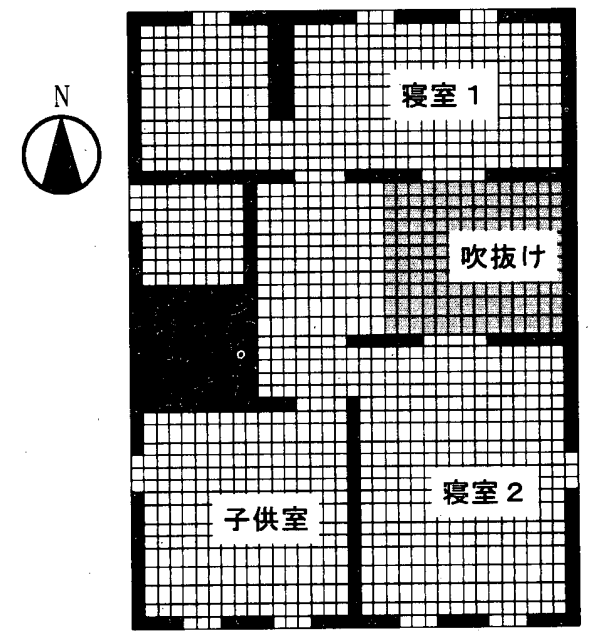

（3） $2 \mathrm{~F} メ ッ シ ュ$ 分割（平面）

図13 実在住宅モデル 
ある住宅の立地する敷地が建蔽率 $10 \%$ の場合、その住宅の立地指標 はGrade 1 となる。

\section{4. 建物性能指標}

室内の気流性状は、開口面積・位置、室内の間取り、建付家具の 設置状況等（本稿ではこれらのパラメータを総合して「建物性能」と 定義）の影響を受けると考えられる。通風により居住者の体感温度 低下の効果を考えるには、これらのパラメータを考虑し、居住空間 において体感温度低下に効果的な気流速度を確保できるかを予測す る必要がある。

そこで、単純住宅モデルおよび実在住宅モデル等について、建物 性能が室内の気流性状に与える影響を解析し、総合通風性能評価指 標の一指標である「(3)建物性能指標」を提案することを目的とする。

\section{1 解析対象モデル}

解析対象モデルは前項で示した単純住宅モデル、日本建築学会住 宅用標準問題モデル及び新潟市に建つ実在住宅モデルを対象とする (図 13)。

\section{2 解析条件}

解析手法は前項と同様である。表 5 に解析条件を、図 14 に東京の 非暖房期間（5月8日〜10月13日）における風配図、風向別平均

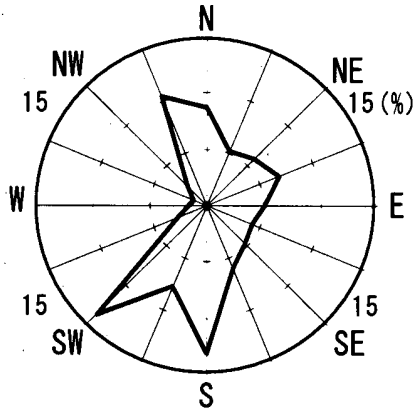

(1) 風配図

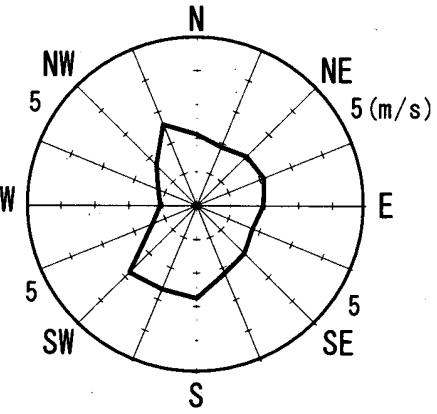

（2）風向別平均風速
図 14 東京の非暖房期間における 風配図、風向別平均風速

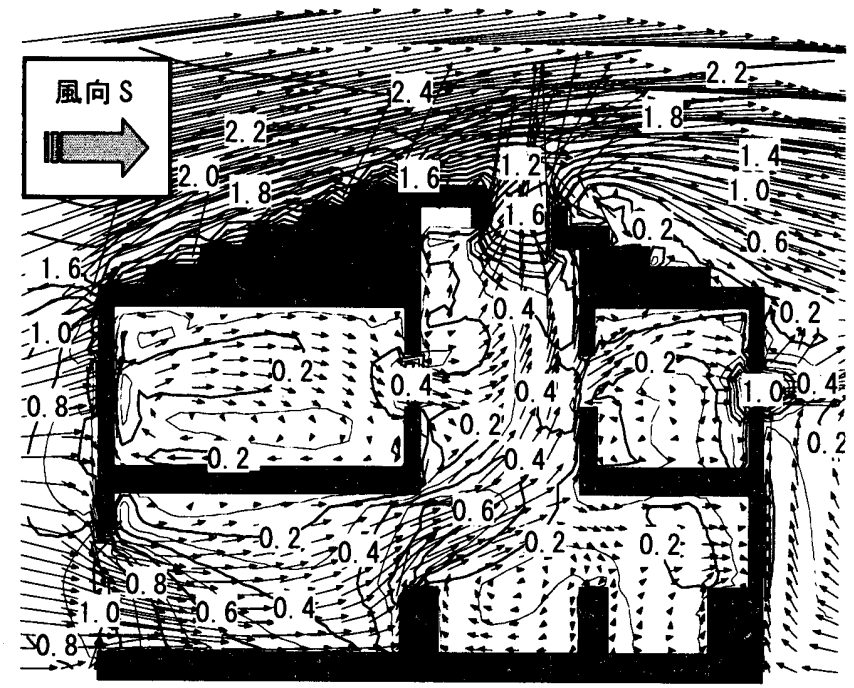

図 15 室内気流分布（風向 $S 、 A-A^{\prime}$ 断面）
風速を示す。解析は 16 風向を対象に行い、その解析結果と対象モデ ルが東京に立地していると仮定して東京の風速、風向データから非 暖房期間平均の風速分布を算出する。建蔽率は $0 \%$ とし流入風の鋁 直分布は $1 / 4$ 乗則を仮定する。評価対象領域とは座位から立位の室 内呼吸域付近であり、床上 $0.5 \sim 1.5 \mathrm{~m}$ と定義する。

単純住宅モデルでは天空の有無をパラメータとして解析を行う。 実在住宅モデルにおいては天空を開放し、建付家具を設置した状況 で解析を行う。

\section{3 解析結果}

図 15 に実在住宅モデルの $A-A$ '断面の室内気流分布（風向 $S$ ）を 示す。 $1 \mathrm{~F} ， 2 \mathrm{~F}$ の南空から流入した外気は居室から吹き抜けを通 り、天空から流出される通気輪道が形成されている。また、1 F 北 側の居室は気流速度 $0.2 \mathrm{~m} / \mathrm{s}$ 以下の比較的遅い気流分布となる。こ れは家具により、南側居室からの流入外気が遮られること、流入し た外気の主流方向に面する開口が無いこと等が原因と考えられる。

\section{4 建物性能指標の評価}

図 16 に各モデルを対象とした平均気流速度の累積頻度の計算結果 を示す。本稿では「建物性能」を評価する尺度として、気流速度 $0.3 \mathrm{~m} / \mathrm{s}$ 以上の容積比を基準として評価を行う。表 6 に居住空間に対 して気流速度 $0.3 \mathrm{~m} / \mathrm{s}$ 以上の容積の割合を示す。表 6 に示寸值は、評 価対象領域内の気流速度 $0.3 \mathrm{~m} / \mathrm{s}$ 以上の容積割合を意味している。

表 6 評価対象領域における風速 $0.3 \mathrm{~m} / \mathrm{s}$ 以上の割合

\begin{tabular}{|c|c|c|c|c|}
\hline & \multicolumn{2}{|c|}{ 単純モデル } & $\begin{array}{c}\text { 標準問 } \\
\text { 題 }\end{array}$ & $\begin{array}{c}\text { 実在住宅 } \\
\text { モデル }\end{array}$ \\
\hline 計算case & case 1 & case2 & case3 & case 4 \\
\hline $\begin{array}{c}\text { 気流速度0.3m/s } \\
\text { 以上の割合 }\end{array}$ & 0.31 & 0.65 & 0.52 & 0.29 \\
\hline
\end{tabular}

表 7 建物性能指標のグレード

\begin{tabular}{c|c}
\hline & 気流速度0.3m/s以上の割合 \\
\hline \hline Grade1 & 0.5 以上 \\
\hline Grade2 & $0.4 \sim 0.5$ 未満 \\
\hline Grade3 & $0.3 \sim 0.4$ 未満 \\
\hline Grade4 & $0.2 \sim 0.3$ 未満 \\
\hline Grade5 & $0 \sim 0.2$ 未満 \\
\hline
\end{tabular}

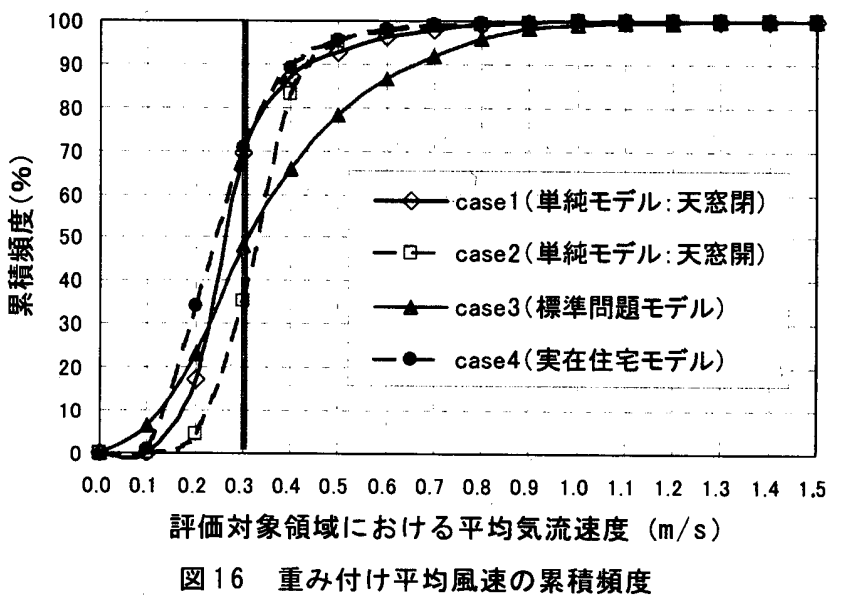


また、表中の值は図 14 に示寸風向別平均風速に基づいて、室内外同時 気流解析の結果から、風向ごとに重み付けをして求めたものである。

対象モデルの基準となる単純住宅モデルでは天空無の case 1 で 0.31 、 天空有の case 2 で 0.65 となり、天空の効果により気流速度 $0.3 \mathrm{~m} / \mathrm{s}$ 以 上の空間割合は大きくなる。

標準問題モデルは 0.52、実在住宅モデルは 0.29 となる。標準問 題モデルでは西面、南面に開口があり、東京の最多風向頻度が S、SW であるため流入外気量が多くなり室内は比較的速い気流速度となっ ている。一方、実在住宅モデルでは西面の開口が少なく、開口面積 も小さいため西側空からの流入外気が少ないこと、および $1 \mathrm{~F} は$ 建 付家具の影響により気流速度が比較的遅くなることなどが原因とな り、気流速度 $0.3 \mathrm{~m} / \mathrm{s}$ 以上の空間割合は小さくなっている。建物性 能は地域の風向・風速頻度、建物の立地する方向、開口位置・面積に 大きな影響を受けており、これらの要素を考慮し、評価を行う必要 があると考えられる。

表 7に建物性能指標のグレードを示す。地域指標、立地指標と同 様に、表 7 に示した評価対象領域における気流速度 $0.3 \mathrm{~m} / \mathrm{s}$ 以上の 容積の割合をGrade 1 から Grade 5 まで 5 段階に分け、評価を行う。 例えば、単純モデルの case 1 (天空無)・が Grade 3、case 2 (天空 有）が Grade 1 となる。

\section{5 建物性能指標のまとめ}

本項では、総合通風性能評価指標の一指標である建物性能の評価を 行った。建物性能指標の評価尺度は評価対象領域における気流速度 $0.3 \mathrm{~m} / \mathrm{s}$ 以上の容積の割合を基準とした。

(1)単純住宅モデルでは、天空の有無により解析を行い天空が有ること により、気流速度 $0.3 \mathrm{~m} / \mathrm{s}$ 以上の割合は天空が無い場合に比較し約 2 倍となり天空の効果が大きい。

(2)標淮問題モデルおよび実在住宅モデルの解析結果から、開口の位置、 面積の違いにより室内気流速度は異なり、建物性能が室内気流速度に 及ぼす影響は大きいと考えられる。

(3)評価対象領域における $0.3 \mathrm{~m} / \mathrm{s}$ 以上の容積の割合を用いて 5 段階 のグレードに分け、建物性能指標の評価指標を作成した。単純モデ ルの case 2 (天空有) が Grade 1 となる。

表 8 総合通風性能評価指標の例

\begin{tabular}{c||c|c}
\hline モデル名 & $\begin{array}{c}\text { 標準問題 } \\
\text { モデル }\end{array}$ & $\begin{array}{c}\text { 実在住宅 } \\
\text { モデル }\end{array}$ \\
\hline 地域指標 & $\begin{array}{c}\text { Grade3 } \\
\text { (東京と仮定) }\end{array}$ & $\begin{array}{c}\text { Grade1 } \\
\text { (新潟と仮定) }\end{array}$ \\
\hline 立地指標 & $\begin{array}{c}\text { Grade2 } \\
(k=30 \% \text { と仮定) }\end{array}$ & $\begin{array}{c}\text { Grade2 } \\
(k=30 \% \text { と仮定) }\end{array}$ \\
\hline $\begin{array}{c}\text { 建物性能 } \\
\text { 指標 }\end{array}$ & Grade1 & Grade4 \\
\hline $\begin{array}{c}\text { 総合通風性能 } \\
\text { 評価指標 }\end{array}$ & Grade2.0 & Grade2.3 \\
\hline
\end{tabular}

\section{5. 総合通風性能評価指標}

$2 \sim 4$ 項では、総合通風性能評価指標のパラメータである地域指 標、立地指標、建物性能指標についてそれぞれ 5 段階のグレードに 分けを行った。本項ではその 3 つのパラメータを用いて総合通風性 能評価指標の試案を示す。

\section{1 評価方法}

3 指標のグレードを足し合わせて単純平均したものを総合通風性 能評価指標のグレードと仮定する。最高值で Grade 1.0、最低值で Grade5.0 となり、值が小さいほど通風性能が良いことを示す。

\section{2 総合通風性能評価指標の評価}

表 8 に総合通風性能評価指標の例を示す。標準問題モデルが東京、 実在住宅モデルが新潟の地域に建てられ、両モデルとも建蔽率 $30 \%$ の敷地に立地していると仮定すると、総合通風性能評価指標は標準 問題モデルでGrade2. 0、実在住宅モデルで Grade2. 3 となる。

\section{3 総合通風性能評価指標のまとめ}

本項では戸建住宅を定量的に評価するための指標として、地域指 標、立地指標、建物性能指標の 3 つ指標を用いて総合通風性能評価 指標の試案を示した。

\section{6.まとめ}

本稿において戸建住宅の総合通風性能評価指標の提案を行った。 「(1)地域指標」では通風デグリアワー（CVDH）を提案し、全国の CVDH マップを作成し 5 段階によりグレード分けを行った。「(2)立地 指標」では建蔽率の変化による平均通風量比を算出し、グレード分 けを行った。「(3)建物性能指標」では建物性能が室内気流性状に及ぼす 影響を解析し、評価対象領域における気流速度 $0.3 \mathrm{~m} / \mathrm{s}$ 以上の容積 の割合を用いて 5 段階のグレード分けを行った。さらに、総合通風 性能評価指標を上記の 3 指標を用いた評価指標の試案を示した。

今後は評価対象モデルを堌し上記の 3 指標を用いて、総合通風性 能評価指標の評価を行う。

注䣋

1 ) 気流速度は人体呼吸域付近の地上から $1.6 \mathrm{~m} の$ 高さの気流速度を用いている。 2 ) 本稿でいう建蔽率は建物周边の道路も含めた建蔽率である。

参考文献

1 ) 赤林他「室内気流分布を考慮した住宅の通風性能評価に関する研究その 1 4 」日本建築学会大会 (関東) 研究報告集, D-2,pp. 627-634, 2001 年 2 ) 赤林・村上他「周辺に建物群のある独立住宅の風圧分布に関する風洞実験および 換気量予測、住宅の換気・通風に関する実験的研究 その1j日本建築学会計画系論 文集, 1994 年

3)村上·加藤・出口「住宅の通風に関する実験的研究 その 2 風洞模型実験によ る検討結果」日本建築学会大会学術講演梗概集, 1983年

4) 村上·加藤·赤林他「住宅の換気通風に関する実験的研究その 8〜10」日本建 築学会大会学術講演梗概集, 1990 年

5 ）小橋・倉淵・大場他「通風時の建物内外気流構造を目的としたLES解析 風向 $0^{\circ}, 45^{\circ}$ の場合のシミュレーション結果とその解析」空気調和・衛生工学会学術 講演会論文集, 2000 年

6)澤地・清田・瀬戸・成田「住宅の通風設計及び性能評価に関する研究 その 9 、 その $10 」$ 日本建築学会大会学術講演梗概集, D-2, pp. 623-626, 2001 年

7 ) 赤坂・二宮他「日本建築学会桩張アメダス気象データ」 日本建築学会、1999 年 12 月 